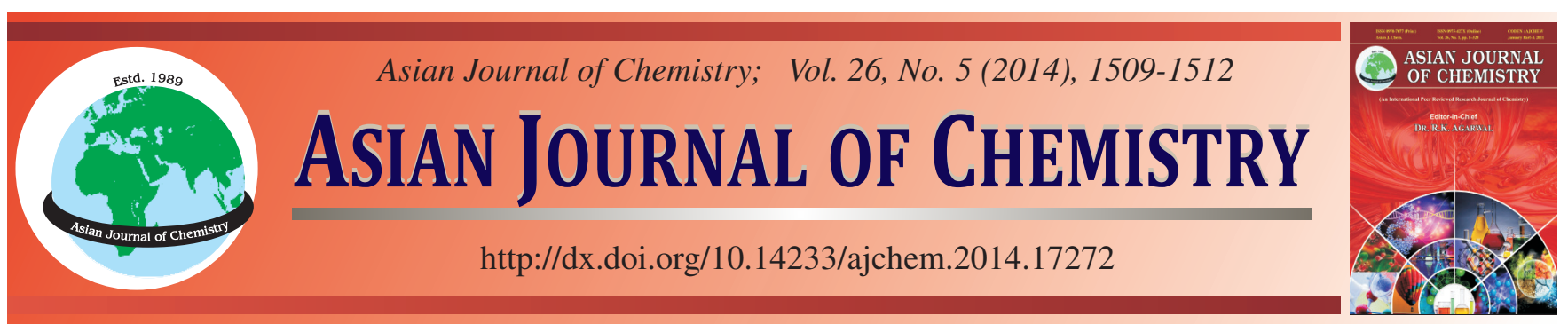

\title{
Influence of Composition and Ratio of Raw Materials on Suspension Property and Compressive Strength of Clay Grouting Material for Coal Mine Gob $\dagger$
}

\author{
Daosheng Sun, Liang Wang, Aiguo Wang ${ }^{*}$ and Jiajia Chen
}

Anhui Key Laboratory of Advanced Building Materials, Anhui Jianzhu University, Hefei 230022, P.R. China

*Corresponding author: Fax: +86 551 3828078; E-mail: wag3134@126.com

\begin{abstract}
The influence of the water-solid ratio, cement and lime dosage on suspension property and compressive strength for clay grouting material is investigated in this paper. The test results show that by increasing the water-solid ratio, the drainage rate of clay grout will be increased while the concretion rate of clay grout will be decreased. Adding the cement and lime, the drainage rate of grouts and the compressive strength will be increased and the concretion rate of grouts will be shortened. The compressive strength of clay-cement-lime grouts reaches to the peak when the lime dosage is $6 \%$. When the cement dosage is $12 \%$, the degree of increase is the largest for compressive strength of clay-cement-lime grouts and the strength is well-developed.
\end{abstract}

Keywords: Grouting materials, Water-solid ratio, Compressive strength, Drainage rate, Concretion rate.

\section{INTRODUCTION}

China is rich in coal resource, that giving priority to coal energy supply pattern is difficult to be changed in quite a long period of time in the future ${ }^{1}$. However, the resource of coal is limited. In order to improve the extraction rate of coal, ensure the security of the gob and promote regenerated roof form, a measure has been taken by grouting. At present clay grouting fly ash grouting and chemical grouting have been belonged to grouting materials of gob. The properties of low-price clay grouting are the heat absorbing, temperature lowering and coal wrapping, but its disadvantages are limited coagulability, poor stability and huge amounts of land resources consumed. The properties of low-hydration fly ash grouting that have disadvantages of weak suspended and poor water retention ${ }^{2}$. Chemical grouting can be injected into the microscopic pore, which has the advantage of low-viscosity. In addition, the environmental contamination and high-price are still existing ${ }^{3}$. The coal mine grouting materials of gob have characteristics of wide range of sources, low-cost, higher-intensity, good controllability and little pollution to environment ${ }^{4}$. Therefore, this paper learnt from the experience of other grouting materials. The influence of water-solid ratio, cement and lime dosage on suspension property and compressive strength for clay grouting material was researched. The optimum cement and lime dosage were obtained for clay-cement-lime grouts.

\section{EXPERIMENTAL}

The clay was obtained from Hefei, Anhui, P.R. China. Ordinary Portland cement 42.5 provided by Hailuo Cement Factory, Wuhu, Anhui, P.R. China was used. The lime was obtained from Qinyang Lime Factory, Hefei, Anhui, P.R. China. Chemical composition of cement, clay and lime is shown in Table-1.

Suspension test: The grouts was poured into a $250 \mathrm{~mL}$ graduated cylinder, meanwhile started the timer and note down the initial scale $H$. Note down the scale $h_{x}$, when the time

\begin{tabular}{|c|c|c|c|c|c|c|c|c|}
\hline \multicolumn{9}{|c|}{$\begin{array}{c}\text { TABLE-1 } \\
\text { CHEMICAL COMPOSITION OF CEMENT, CLAY AND LIME (\%) }\end{array}$} \\
\hline Composition & $\mathrm{SiO}_{2}$ & $\mathrm{Fe}_{2} \mathrm{O}_{3}$ & $\mathrm{Al}_{2} \mathrm{O}_{3}$ & $\mathrm{CaO}$ & $\mathrm{Mg} \mathrm{O}$ & $\mathrm{SO}_{3}$ & $\mathrm{~K}_{2} \mathrm{O}$ & $\mathrm{Na}_{2} \mathrm{O}$ \\
\hline Cement & 20.29 & 3.69 & 4.46 & 63.72 & 1.47 & 1.59 & 0.68 & 0.21 \\
\hline Clay & 66.05 & 6.04 & 12.84 & 1.43 & 1.06 & 0.23 & 1.59 & 0.90 \\
\hline Lime & 0.37 & 1.21 & 92.5 & 1.23 & 0.45 & 3.12 & - & - \\
\hline
\end{tabular}

†Presented at The 7th International Conference on Multi-functional Materials and Applications, held on 22-24 November 2013, Anhui University of Science \& Technology, Huainan, Anhui Province, P.R. China 
arrived at $3,5,10,15,20,30,40,50$ and $60 \mathrm{~min}$. At last, the volume of the concretion bodies were measured and noted down the scale $\mathrm{h}_{24}$ after $24 \mathrm{~h}$. The drainage rate of grouts and the concretion rate of grouts were calculated by the formulae (1-2).

$$
\begin{gathered}
\mathrm{D}_{\mathrm{x}}=\frac{\mathrm{H}-\mathrm{h}_{\mathrm{x}}}{\mathrm{H}} \times 100 \% \\
\mathrm{C}_{\mathrm{x}}=\frac{\mathrm{h}_{24}}{\mathrm{H}} \times 100 \%
\end{gathered}
$$

where $D_{x}$ is the drainage rate of grouts, $C_{x}$ is the concretion rate of grouts.

Strength test: $40 \mathrm{~mm} \times 40 \mathrm{~mm} \times 40 \mathrm{~mm}$ specimens were obtained and the water-solid ratio was 0.55 . Specimens were striped when they were conserved in the specified conditions $\left(20 \pm 5^{\circ} \mathrm{C}, 75 \%\right.$ humidity) for $24 \mathrm{~h}$. Then compressive strength of specimens was determined by hydraulic testing machine at $2 \mathrm{~mm} / \mathrm{min}$ load rate in the prescribed age.

\section{RESULTS AND DISCUSSION}

Influence of lime dosage on drainage rate and concretion rate of clay grout: Figs. 1 and 2 show that maintaining the water-solid ratio (4:1) unchanged. Adding the lime, the drainage rate of clay grout is increased markedly, but the concretion rate is decreased. The drainage rate of clay grout is increased with time. When lime dosage is increased, the drainage rate of clay grout is increased while the concretion rate is increased and then decreased. For $3 \%$ and $6 \%$ lime dosage, the drainage rate of clay grout is less than others. For $6 \%$ lime dosage, the concretion rate of clay grout is the highest.

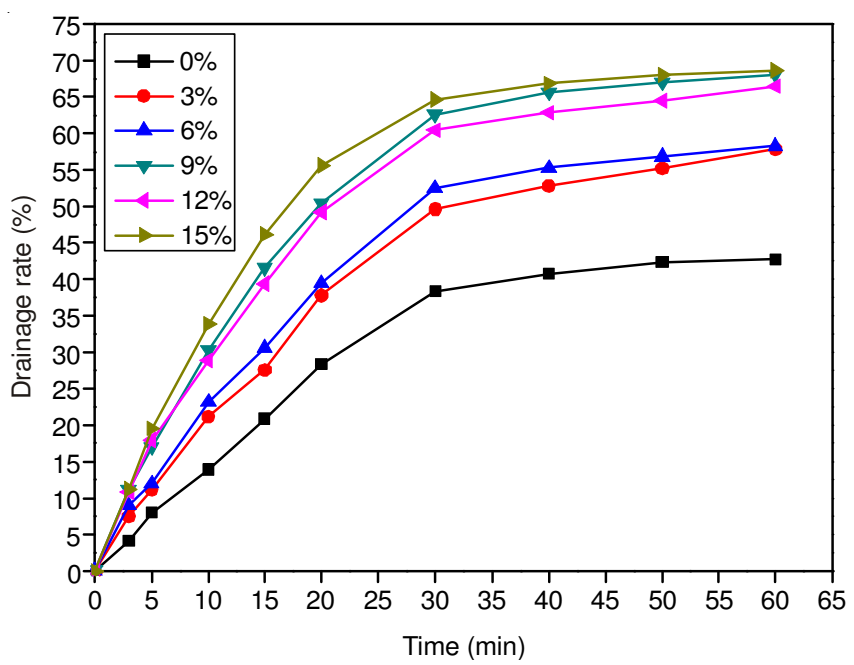

Fig. 1 Influence of lime dosage on drainage rate of clay grout

Because of the ion-exchanges reaction $\left[\mathrm{K}^{+}\left(\mathrm{Na}^{+}\right)+\mathrm{Ca}^{2+}\right.$ $\left.\rightarrow\left(\mathrm{Ca}^{2+}\right)+2 \mathrm{~K}^{+}\left(\mathrm{Na}^{+}\right)\right]$between the lime and clay, water film of the clay particle surface will becomes thin gradually and finally the drainage rate of clay grout will be reduced. When the lime dosage is increased, the drainage rate of clay grout will be increased and the water film will be ruptured. The ionexchanges reaction and the aggregation effect between the lime and clay will be happened after the grouts gradually stabilized, the grouts will gel gradually and form "grid structure" . At

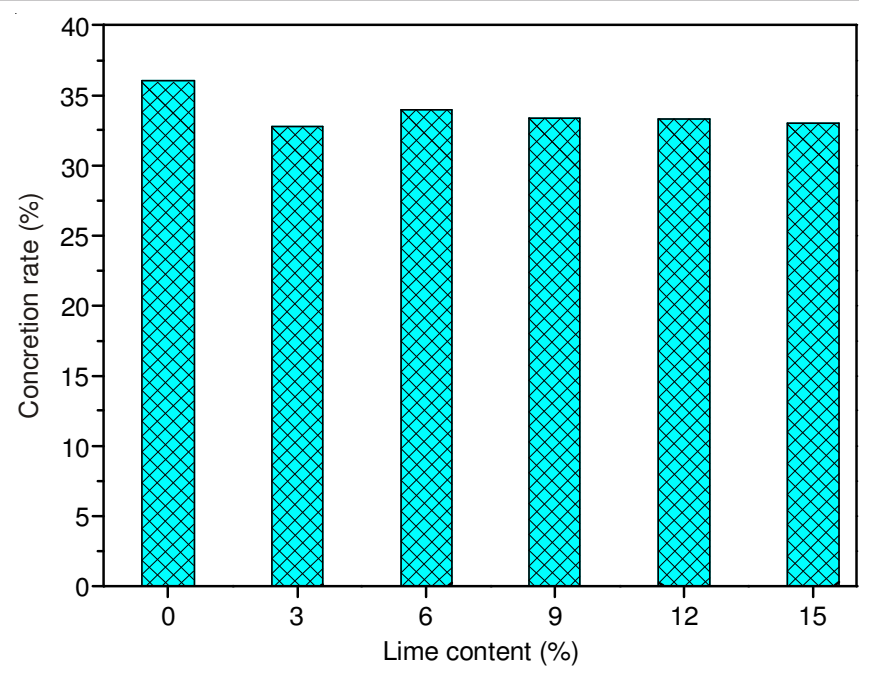

Fig. 2. Influence of lime dosage on concretion rate of clay grout

last, this "grid structure" will be broken and the concretion rate of grouts will be shortened with the lime dosage increasing. For $6 \%$ lime content, the drainage rate and concretion rate of clay grout are all good.

Influence of cement dosage on the drainage rate and concretion rate of clay grout: Figs. 3 and 4 show that maintaining the water-solid ratio (4:1) unchanged. Adding the cement, the drainage rate of clay grout is increased, but the concretion rate is decreased. The drainage rate of clay grout is increased with time. When dosage of the cement is increased, the drainage rate of clay grout is increased; the concretion rate of clay grout is decreased. The "clay cement ball" will be formed because of the electric charge effect between the cement and clay $^{6}$. The drainage rate and concretion rate of clay grout will be changed by the ion-exchanges reaction and hydration. In conclusion, cement dosage has some impact on the drainage rate and concretion rate of clay grout.

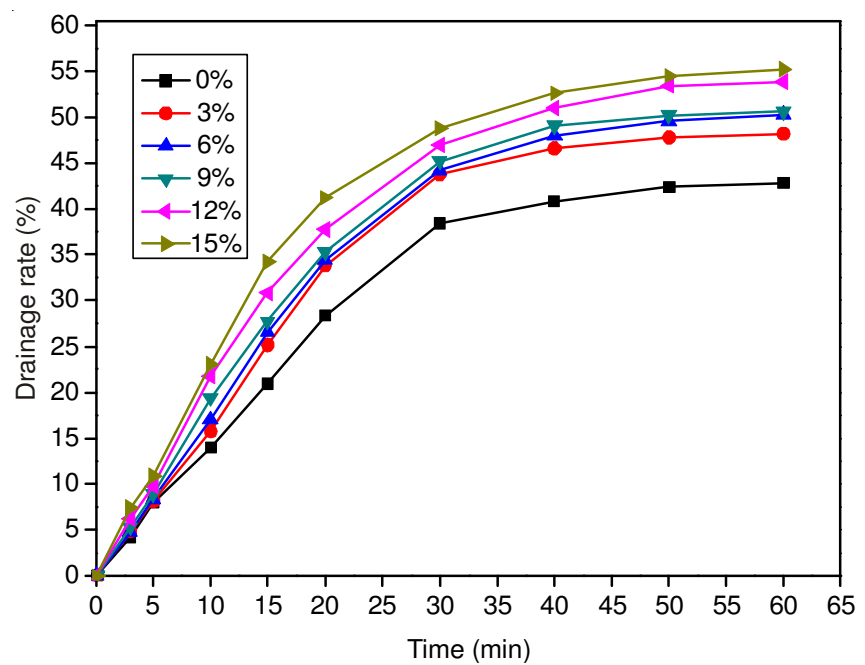

Fig. 3. Influence of cement dosage on drainage rate of clay grout

Influence of water-solid ratio on the drainage rate and concretion rate of clay grout: Figs. 5 and 6 showed that the increasing the water-solid ratio, the drainage rate of clay grout is improved, the concretion rate is decreased. The drainage rate of clay grout is improved with time. In conclusion, water- 


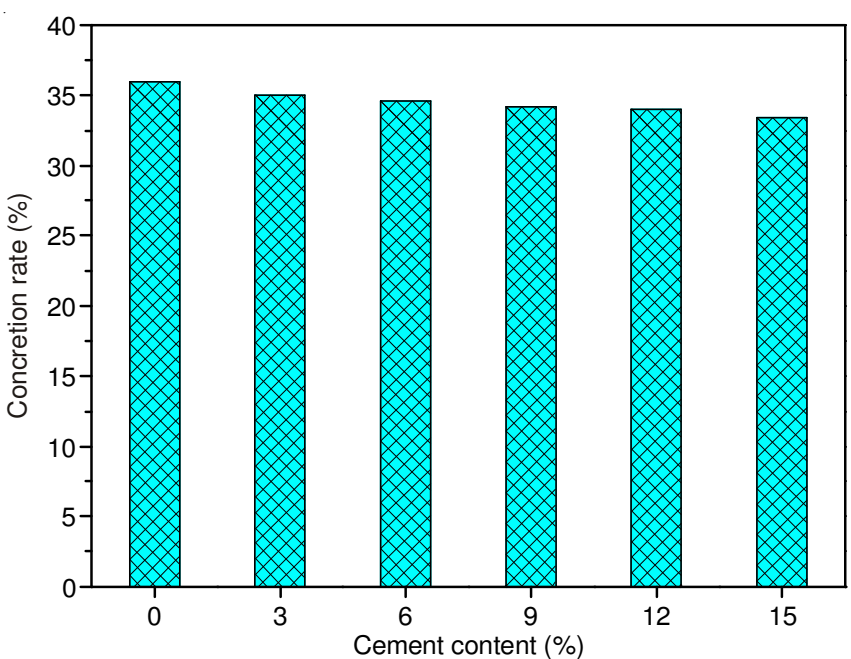

Fig. 4. Influence of cement dosage on concretion rate of clay grout

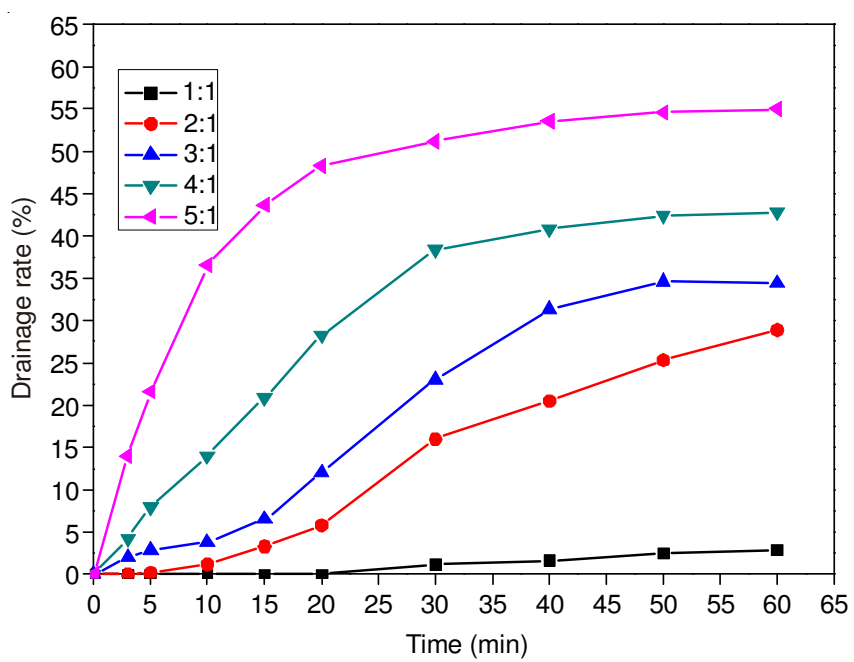

Fig. 5. Influence of water-solid ratio on the drainage rate of clay grout

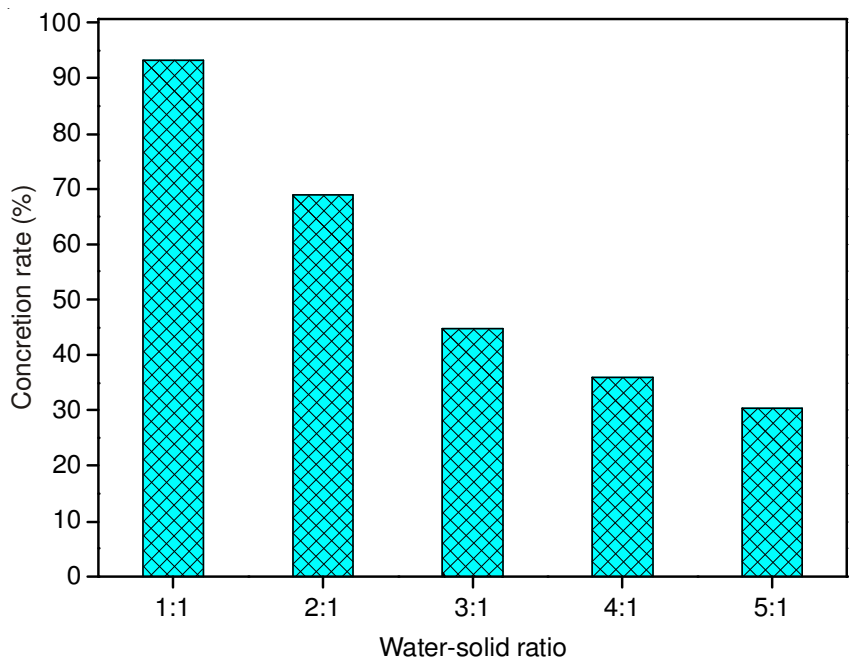

Fig. 6. Influence of water-solid ratio on the concretion rate of clay grout

solid ratio has a great influence of drainage rate and concretion rate for clay grouting material.

Influence of cement dosage on the compressive strength of clay grout: Fig. 7 shows that, when dosage of the cement is increased, the compressive strength of clay grout is improved. When the cement dosage is $12 \%$, the degree of increase is the

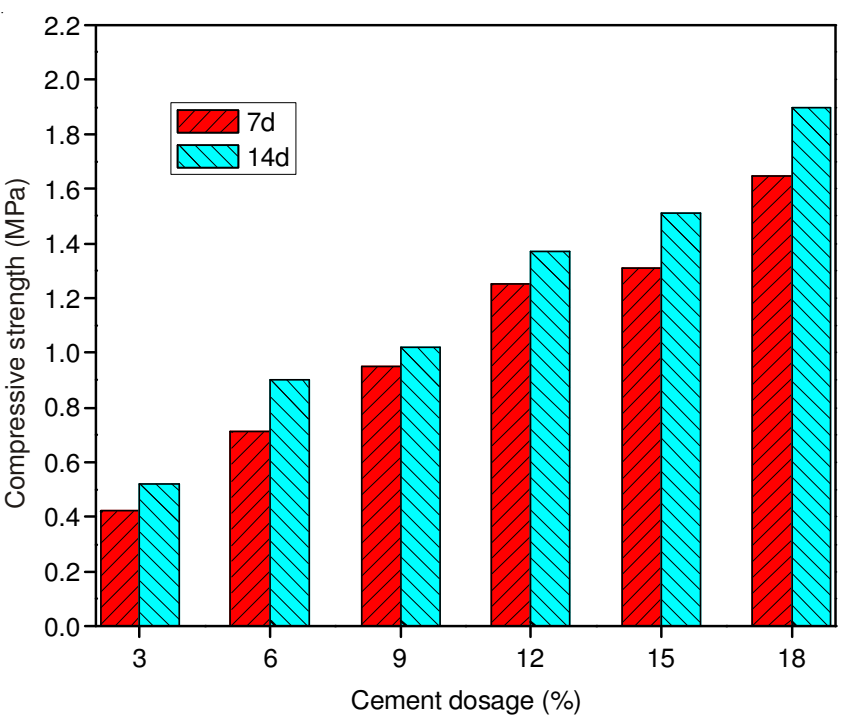

Fig. 7. Influence of cement dosage on the compressive strength of clay grouts

largest. Adding the cement, the maximum strength is increased by 4 times than the original. It shows that dosage of cement has a great effect on strength of clay grout and has adjustability of the strength. Hydration reaction occurs after the cement is added to the clay grout, which can produce hydrated calcium silicate $(\mathrm{C}-\mathrm{S}-\mathrm{H})$, hydrated calcium aluminates $(\mathrm{C}-\mathrm{A}-\mathrm{H})$, amorphous gel and $\mathrm{Ca}(\mathrm{OH})_{2}$. The grouts will gel gradually until at last it will be hardened ${ }^{6-9}$. The possible chemical reactions had been selected as follows.

$$
\begin{gathered}
\mathrm{SiO}_{2}+3 \mathrm{Ca}(\mathrm{OH})_{2}+\mathrm{nH}_{2} \mathrm{O}_{\mathrm{y}} \rightarrow 3 \mathrm{CaO} \cdot \mathrm{SiO}_{2} \cdot(\mathrm{n}+3) \mathrm{H}_{2} \mathrm{O}_{\mathrm{y}} \\
3 \mathrm{Ca}(\mathrm{OH})_{2}+\mathrm{Al}_{2} \mathrm{O}_{3}+\mathrm{nH}_{2} \mathrm{O}_{\mathrm{y}} \rightarrow 3 \mathrm{CaO} \cdot \mathrm{Al}_{2} \mathrm{O}_{3} \cdot(\mathrm{n}+3) \mathrm{H}_{2} \mathrm{O}_{\mathrm{y}}
\end{gathered}
$$

Influence of lime dosage on the compressive strength of clay-cement grouts: Fig. 8 shows that, maintaining cement dosage (12\%) unchanged. Adding the lime, the compressive strength of clay-cement grouts is improved. The compressive strength of grouts is increased and then decreased with the lime dosage increasing. Meanwhile the compressive strength of grouts reaches to the peak when the lime dosage is $6 \%$. The compressive strength is increased by nearly $30 \%$ compare with the component of non-doped lime. Physical and chemical reactions between lime and grouts will be happened, such as hydration, ion-exchange and aggregation effect, hard coagulation reaction and carbonation. The more lime dosage is added, the more strength of clay-cement grouts is increased. However, when the lime dosage is increased more than the best one, the strength of grouts will be decreased. In conclusion, lime dosage has a great influence of compressive strength of clay-cement grouts. When the lime dosage is $6 \%$, the strength of grouts reaches to the peak. The possible chemical reactions had been selected as follows:

$$
\begin{gathered}
\mathrm{CaO}+\mathrm{H}_{2} \mathrm{O} \rightarrow \mathrm{Ca}(\mathrm{OH})_{2} \rightarrow \mathrm{Ca}^{2+}+2 \mathrm{OH}^{-} \\
\mathrm{SiO}_{2}+3 \mathrm{Ca}(\mathrm{OH})_{2}+\mathrm{nH}_{2} \mathrm{O}_{\mathrm{y}} \rightarrow 3 \mathrm{CaO} \cdot \mathrm{SiO}_{2} \cdot(\mathrm{n}+3) \mathrm{H}_{2} \mathrm{O}_{\mathrm{y}} \\
3 \mathrm{Ca}(\mathrm{OH})_{2} \mathrm{Al}_{2} \mathrm{O}_{3}+\mathrm{nH}_{2} \mathrm{O}_{\mathrm{y}} \rightarrow 3 \mathrm{CaO} \cdot \mathrm{Al}_{2} \mathrm{O}_{3} \cdot(\mathrm{n}+3) \mathrm{H}_{2} \mathrm{O}_{\mathrm{y}} \\
\mathrm{Al}_{2} \mathrm{O}_{3} \cdot 2 \mathrm{SiO}_{2} \cdot 2 \mathrm{H}_{2} \mathrm{O}+\mathrm{mCa}(\mathrm{OH})_{2}+\mathrm{nH}_{2} \mathrm{O} \rightarrow \\
\mathrm{mCaO} \cdot \mathrm{Al}_{2} \mathrm{O}_{3} \cdot 2 \mathrm{SiO}_{2} \cdot(\mathrm{n}+2) \mathrm{H}_{2} \mathrm{O}
\end{gathered}
$$

Influence of cement dosage on the compressive strength of clay-lime grouts: It is seen in Figs. 9 and 10 that maintaining 


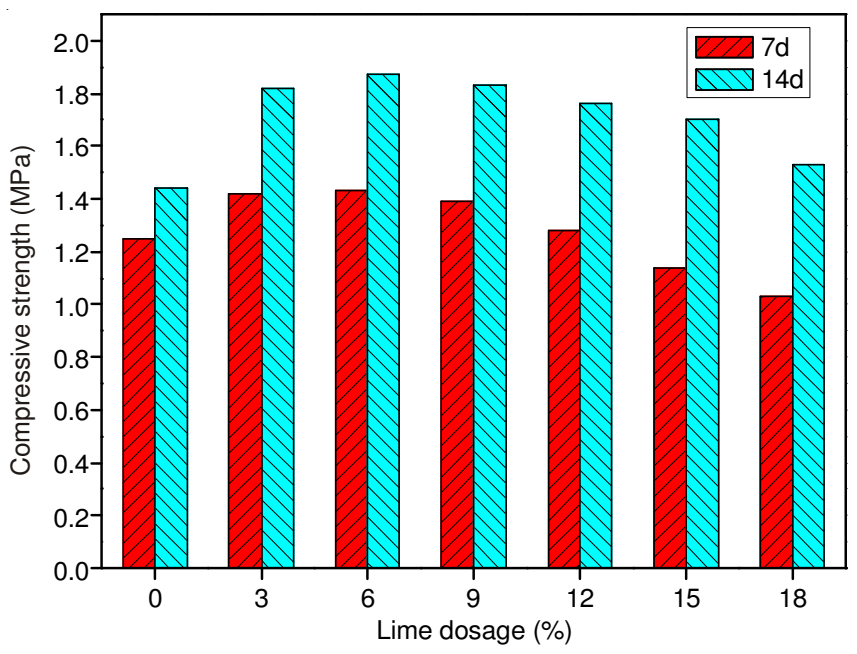

Fig. 8. Influence of lime dosage on the compressive strength of clay-cement grouts

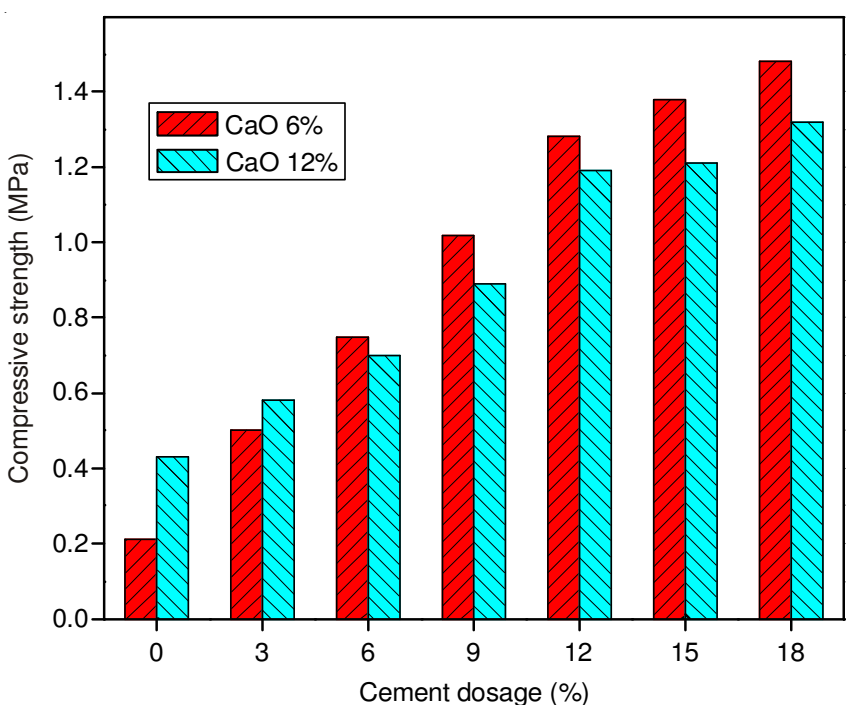

Fig. 9. Influence of cement dosage on the compressive strength of claylime grouts $(7 \mathrm{~d})$

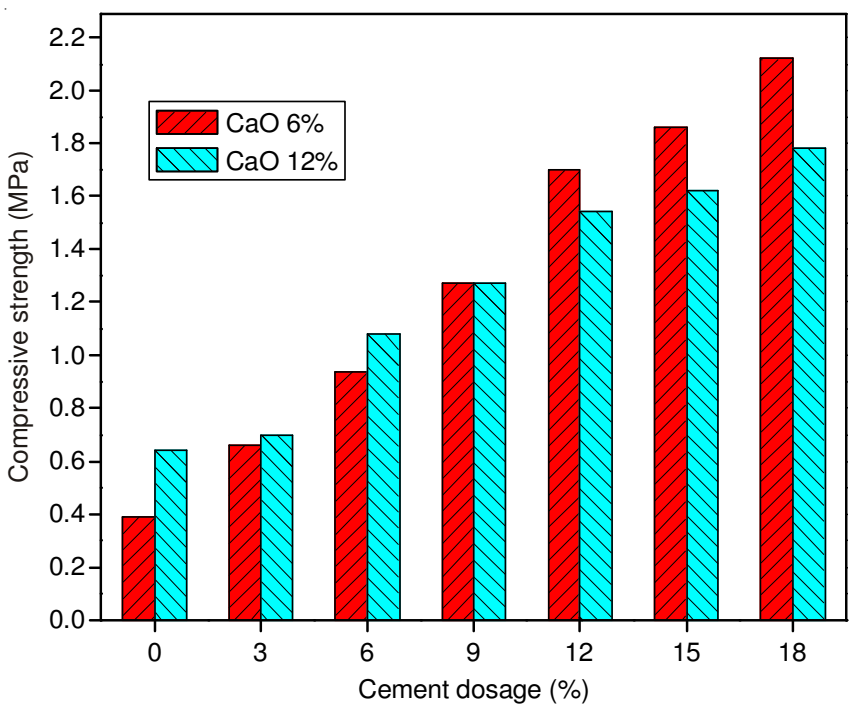

Fig. 10. Influence of cement dosage on the compressive strength of claylime grouts $(14 \mathrm{~d})$ lime dosage ( $6 \%$ and $12 \%$ ) unchanged. Adding the cement, the compressive strength of clay-lime grouts is improved markedly. When dosage of the cement is increased, the compressive strength of grouts is increased and the maximum strength is increased 4.4 times than the original. Comparing with $6 \%$ and $12 \%$ lime dosage, the former has lower strength than the latter in the beginning.

However, when the dosage of the cement is increased, the former has higher strength than the latter gradually. Extra, when the dosage of cement is $12 \%$, the component of $6 \%$ lime dosage has higher compressive strength all the time and the degree of increase for compressive strength is the largest whatever lime dosage and ages. In conclusion, cement dosage has a great influence of compressive strength of clay-lime grouts. When the lime dosage is $6 \%$ and cement dosage is $12 \%$, clay-cement-lime grouts can result in better performance.

\section{Conclusions}

- Water-solid ratio has a great influence of drainage rate and concretion rate for clay grouting material. Increasing the water-solid ratio the drainage rate of clay grout will be improved, the concretion rate will be decreased.

- Adding the lime, the drainage rate of clay grout will be increased; the concretion rate of clay grout will be shortened; the compressive strength of clay-cement grouts will be improved. The strength of clay-cement grouts is increased and then decreased with the lime dosage increasing. Extra, the compressive strength of clay-cement-lime grouts reaches to the peak when the lime dosage is $6 \%$.

-Adding the cement, the drainage rate and the compressive strength of clay grout will be increased while the concretion rate of clay grout will be shortened. The compressive strength of clay-lime grouts is increased with the cement dosage increasing. When the cement dosage is $12 \%$, the degree of increase is the largest for compressive strength of clay-cement-lime grouts and the strength is well-developed.

\section{ACKNOWLEDGEMENTS}

This research is financially supported by the Huainan Mining Group Scientific Research Project.

\section{REFERENCES}

J.L. Wang, L.Y. Feng and G.E. Tverberg, Energy Policy, 57, 542 (2013). Z.M. Luo and X. Liu, Coal Eng., 12, 39 (2007).

3. C. Liu and S. Lu, J. China Univ. Mining Technol., 29, 454 (2000).

4. H. Li, J. Highway Transportation Res. Develop., 28, 35 (2011).

5. Q. Qi, X. Sheng and Y. Dong, Chem. Ind. Times, 21, 29 (2007).

6. Q. Xue, J.-S. Li and L. Liu, Appl. Clay Sci., 80-81, 438 (2013).

7. X. Wang, Chin. J. Geotechnical Eng., 21, 34 (1999).

8. Y. Guo, R. Xu and Y. Shao, J. Zhenjiang Univ., 42, 1071 (2008).

9. X. Wang and Z.V. Solymár, Tunnel. Underground Space Technol., 12, 461 (1997). 